\title{
PRESTASI BELAJAR AKUNTANSI DENGAN METODE RESITASI BAHAN AJAR LEMBAR KERJA SISWA KELAS XI AKUNTANSI 2 SMK NEGERI 1 RENGAT
}

\author{
Yetma Martati ${ }^{1}$ \\ ${ }^{1}$ SMK Negeri 1 Rengat \\ e-mail: 1yetma.martati@gmail.com
}

\begin{abstract}
Abstrak
Tujuan penelitian adalah a) meningkatkan pelaksanaan pembelajaran akuntansi keuangan dengan metode resitasi bahan ajar Lembar Kerja Siswa, b) meningkatkan pola pengajaran guru, c) meningkatkan peran serta dan antusiasme siswa dalam melaksanakan pembelajaran dan d) meningkatkan kemampuan dan prestasi siswa dalam pembelajaran akuntansi keuangan. Pelaksanaan Penelitian Tindakan Kelas ini terdiri dari empat siklus, dimana setiap siklus terdiri dari empat komponen yaitu : 1) Perencanaan (planning), 2) Aksi/ Pelaksanaan tindakan (acting), 3) Observasi (obseving), 4) Refleksi (refleting). Jenis data dalam penelitian terdiri dari Data Primer berupa data yang diperoleh secara langsung melalui observasi terhadap aktivitas siswa, dan Data Sekunder berupa data yang diperoleh dari sumber-sumber kepustakaan dan literatur yang terkait. Berdasarkan hasil penelitian dapat disimpulkan bahwa metode ini terbukti mampu meningkatkan aktivitas dan prestasi siswa sehingga tepat untuk diterapkan pada pembelajaran. Peningkatan ini menunjukkan bahwa penerapan metode pembelajaran yang tepat dilakukan melalui peningkatan kemampuan menjelaskan materi sehingga menarik dan memotivasi siswa untuk rajin belajar.
\end{abstract}

Kata kunci: Hasil Belajar, Metode Resitasi bahan ajar, Siswa, SMK Negeri 1 Rengat

\begin{abstract}
The objectives of the study are a) to improve the implementation of accounting learning by recitation methods of Student Worksheet teaching materials, b) improve teacher discussion patterns, c) increase participation and encourage students to do learning and d) improve students' abilities and achievements in learning financial accounting. Implementation of Classroom Action Research consists of four cycles, where each cycle consists of four components, namely: 1) Planning (planning), 2) Action / implementing action (acting), 3) Observation (observing), 4) Reflection (refilling). The type of data in this study consists of Primary Data consisting of data obtained directly through the collection of students, and Secondary Data consisting of data obtained from literature sources and related literature. Based on the results of the study it can be concluded that this method is proven to be able to increase student activity and achievement so that it is suitable to be applied to learning. This improvement explains how to apply appropriate learning methods through increasing the ability to explain the material so that it attracts and motivates students to study hard.
\end{abstract}

Keywords: Learning Achievemnet, Direct Learning, Student, SMK Negeri 1 Rengat 


\section{Pendahuluan}

Pembelajaran akuntansi bagi siswa SMK meliputi pengertian dasar dan siklus akuntansi, metode kuantitatif dalam akuntansi dan keterampilan akuntansi. Agar akuntansi menjadi pelajaran yang menarik dan diminati siswa, maka diharapkan guru dapat memilih metode pembelajaran yang dapat memotivasi siswa. Kegiatan belajar mengajar yang dapat memotivasi siswa adalah melibatkan siswa belajar secara aktif secara fisik, mental maupun sosial. Menurut Paget (2001), Akuntansi merupakan materi pelajaran yang membutuhkan penalaran tinggi, sehingga siswa dituntun untuk mampu memahami konsep-konsep abstrak benda dengan atau tanpa praktek secara langsung. Dengan demikian, sebagai guru sudah semestinya menjadi fasilitator siswa untuk mengembangkan nalar siswa dalam belajar.

Bagi sebagian Siswa SMK bukanlah suatu hal yang mudah untuk memahami suatu konsep yang abstrak, khususnya konsep-konsep dalam mata pelajaran Akuntansi. Terdapat beberapa permasalahan yang terjadi di SMK Negeri 1 Rengat khususnya pada Mata pelajaran Akuntansi yaitu minat belajar yang sangat rendah. Dominasi metode ceramah yang digunakan oleh guru menjadikan pembelajaran Akutansi tidak menarik minat belajar siswa. Hal ini menunjukkan bahwa guru masih belum memanfaatkan secara maksimal berbagai metode yang tepat untuk mendapatkan hasil yang memuaskan. Tujuan penulisan penelitian untuk untuk memperoleh solusi yang tepat guna mengatasi berbagai permasalahan yang dimaksudkan tersebut. Solusi yang ditawarkan tentu saja bersifat sangat preventif guna kebaikan bersama, sehingga dapat meningkatkan kemampuan dan menigkatkan prestasi siswa dalam bidang studi Akuntansi.

Penelitian ini dibatasi yaitu meningkatkan aktivitas dan prestasi belajar siswa dengan metode resitasi bahan ajar lembar kerja siswa. Pelaksanaan penelitian tindakan Kelas ini di batasi dalam skala mikro yaitu pada siswa Kelas XI Akuntasi 2 di SMK Negeri I Rengat pada pembelajaran akuntansi. Melalui pembatasan masalah ini diharapkan agar penelitian ini fokus terhadap tujuan yang telah ditetapkan peneliti dan tidak melebar kedalam disiplin ilmu lainnya.

Metode resitasi adalah metode pembelajaran oleh guru dengan memberikan tugas tertentu agar siswa melakukan kegiatan belajar dan tugas yang diberikan kepada siswa dapat dilakukan di dalam kelas, di halaman sekolah, di laboratorium, di perpustakaan, atau di mana saja asal tugas itu dapat dikerjakan. Tugas atau resitasi tidak sama dengan pekerjaan rumah, tetapi jauh lebih luas dari itu, karena tugas dapat dilaksanakan di rumah, sekolah, perpustakaan, dan di tempat lainnya. Tugas atau resitasi dapat merangsang anak untuk aktif belajar baik secara individual maupun secara kelompok.

\section{Metode Penelitian}

\subsection{Waktu dan Tempat}

Penelitian tindakan kelas ini dilaksanakan pada semester ganjil tahun pelajaran 2017/2018 selama kurun waktu 3 (tiga) bulan mulai dari Agustus sampai Oktober 2017. Penelitian tindakan kelas ini dilaksanakan di SMK Negeri I Rengat yang beralamatkan di Jalan Sultan KM 4 Rengat, Indragiri Hulu, Riau. Penentuan lokasi penelitian ini lebih didasarkan pada kemudahan dalam memperoleh data, dimana peneliti sendiri adalah guru pengampu yang memberikan pembelajaran Akuntansi pada siswa. Sehingga peneliti dapat melakukan pengamatan langsung dan tidak mengganggu kewajibannya sebagai tenaga pendidik.

\subsection{Rancangan Penelitian}

Penelitian tindakan kelas ini dilaksanakan dalam 3 siklus dengan perencanaan kegiatan sebagai berikut

\begin{tabular}{crcccc}
\hline No & Tanggal & Pert & Siklus & Materi & Waktu \\
\hline $\mathbf{1}$ & 14 Agustus 2017 & 1 & 1 & Memproses dokumen dana kas kecil & 2 Jp \\
$\mathbf{2}$ & 21 Agustus 2017 & 2 & 1 & Memproses dokumen dana kas kecil & 2 Jp \\
\hline
\end{tabular}




\begin{tabular}{|c|c|c|c|c|c|}
\hline No & Tanggal & Pert & Siklus & Materi & Waktu \\
\hline 3 & 24Agustus 2017 & 1 & 2 & $\begin{array}{l}\text { Menghitung dan mencatat selisih } \\
\text { dana kas kecil }\end{array}$ & $2 \mathrm{Jp}$ \\
\hline 4 & 28 Agustus 2017 & 1 & 4 & Mengisi dana kas kecil & $2 \mathrm{Jp}$ \\
\hline 5 & 31 Agustus 2017 & 1 & 4 & $\begin{array}{l}\text { Mencatat mutasi dan selisih dana kas } \\
\text { kecil }\end{array}$ & $2 \mathrm{Jp}$ \\
\hline 6 & 4 september 2017 & 2 & 4 & $\begin{array}{l}\text { Mencatat mutasi dan selisih dana kas } \\
\text { kecil }\end{array}$ & $2 \mathrm{Jp}$ \\
\hline 7 & 7 september 2017 & 3 & 4 & $\begin{array}{l}\text { Mencatat mutasi dan selisih dana kas } \\
\text { kecil }\end{array}$ & $2 \mathrm{Jp}$ \\
\hline
\end{tabular}

\subsection{Subjek Penelitian}

Subjek dalam penelitian ini adalah kajian utama dalam penelitian ini karena penelitian ini merupakan partisipasi kolaboratif, dimana peneliti ikut serta dalam aktivitas pembelajaran untuk melakukan penelitian. Objek dalam penelitian yaitu siswa Kelas XI Akuntasi 2 sebanyak 34 siswa yang terdiri dari 14 siswa laki-laki dan 20 siswa perempuan.

\subsection{Sumber dan Teknik Pengumpulan Data}

Data yang digunakan dan dikumpulkan dalam penelitian ini adalah data yang berupu , hasil observasi dan hasil belajar. Jenis data dalam penlitian ini dikelompokkan sebagai berikut:

a. Data Aktivitas Belajar

Data aktivitas belajar merupakan data yang diperoleh dari hasil observasi guru terhadap proses pembelajaran yaitu memperhatikan penjelasan guru, bertanya, mecatat, mengerjakan lembar kerja siswa, menjawab pertanyaan, membuat kesimpulan, dan mengerjakan soal latihan.

b. Data Hasil Belajar

Data hasil belajar terdiri atas dua yaitu hasil belajar kelompok dan hasil belajar individu. Hasil belajar kelompok meliputi keaktifan menjelaskan materi, mendengarkan penjelasan teman, menjawab pertanyaan kelompok, dan menghargai pendapat teman. Sedangkan hasil belajar individu diperoleh dari hasil tes formatif setelah selesai satu siklus.

c. Data Hasil Kinerja Guru

\subsection{Teknik Analisis Data}

Teknik analisis data dalam Penelitian Tindakan Kelas ini menggunakan analisis deskriptif. Kegiatan analisis dengan menganalisis data yang didasarkan pada kualitas data yang digunakan untuk memecahkan permasalahan pokok penelitian, kemudian diuraikan dalam bentuk bahasa deskriptif.

Teknik analisis data aktivitas belajar siswa pada setiap siklus dilakukan dengan cara mengisi lembar pengamatan. Jumlah skor kemudian dipersentase dan dikategorikan berdasarkan kategori berikut: 
Tabel 1. Kategori Aktivitas Belajar Siswa

\begin{tabular}{ccc}
\hline No & Presentase & Kategori Aktivitas Siswa \\
\hline $\mathbf{1}$ & $>71$ & Aktif \\
$\mathbf{2}$ & $61-70$ & Cukup aktif \\
$\mathbf{3}$ & $<60$ & Kurang aktif \\
\hline
\end{tabular}

Teknik analisis hasil kerja kelompok, hasil belajar individu, dan hasil kinerja guru diperoleh dengan menggunakan perbandingan sebagai berikut:

$$
\text { Nilai Akhir }=\frac{\text { Skor yang diperoleh }}{\text { Skor Maksimal }}
$$

Selanjutnya nilai rata-rata hasil belajar siswa dihitung dengan menggunakan rumus ratarata hitung:

$$
\bar{x}=\frac{\sum x i}{n}
$$

$$
\begin{array}{ll}
\text { Keterangan : } & \\
\bar{x} & =\text { Nilai rata-rata yang dicari } \\
\sum x i & =\text { jumlah nilai } \\
n & =\text { Jumlah aspek yang dinilai }
\end{array}
$$

\subsection{Prosedur Penelitian}

Pelaksanaan Penelitian Tindakan Kelas ini terdiri dari tiga siklus, dimana setiap siklus terdiri dari empat komponen yaitu : 1) Perencanaan (planning), 2) Aksi/ Pelaksanaan tindakan (acting), 3) Observasi (obseving), 4) Refleksi (refleting). Dimana setiap siklus saling berkaitan dan berhubungan, karena hasil refleksi akan digunakan sebagai acuan untuk perbaikan pada siklus berikutnya. Diharapkan setiap siklus ada peningkatan yang signifikan mengenai peningkatan pembelajaran Akuntansi Keuangan sehingga hasil akhir akan maksimal. Peneliti mengadakan perubahan dan peningkatan dalam melaksanakan pembelajaran di setiap siklusnya. 
Plan

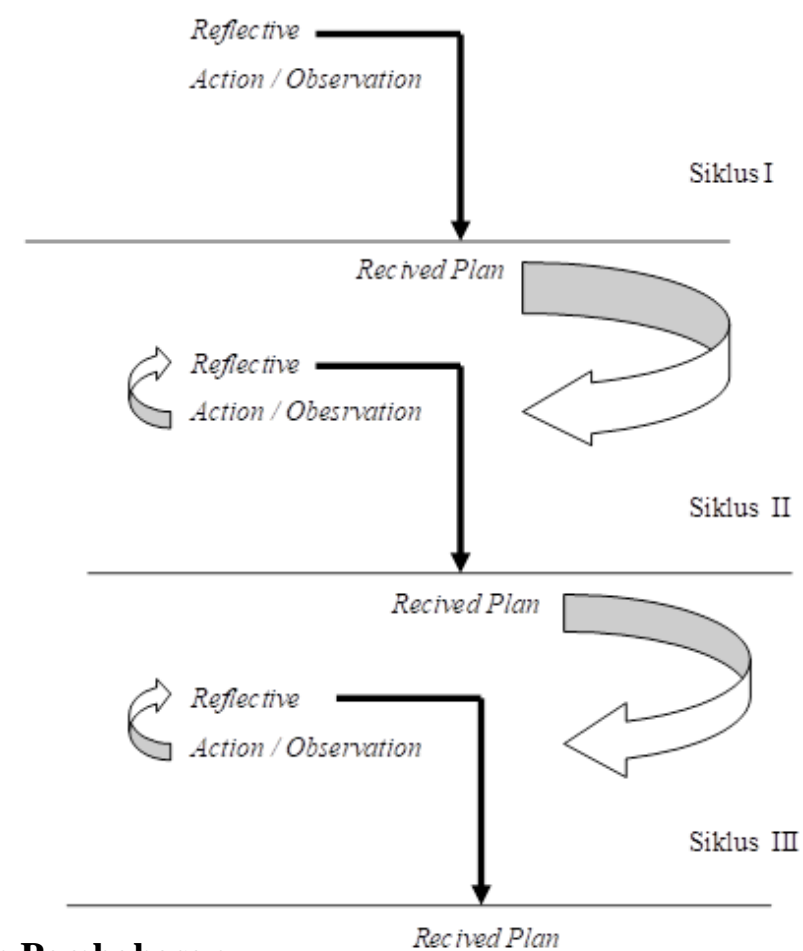

3. Hasil dan Pembahasan

Recived Plan

\subsection{Deskripsi Pra Siklus}

Kondisi pra siklus merupakan kondisi dimana sebelum diterapkan metode resitasi bahan ajar untuk memposting tarnsaksi pembelian dan penjualan ke dalam buku besar. Dimana pelaksanaan pembelajaran Akuntansi Keuangan masih menggunakan metode pembelajaran yang tradisional, dengan cara guru ceramah didepan Kelas untuk menyampaiakan materi pelajaran dan siswa memperhatikannya dibelakang. Metode ini dinilai kurang efektif sehingga siswa tidak dapat menyerap ilmu pelajaran yang disampaikan. Hal ini berimbas pada nilai akademis yang diperoleh siswa menjadi rendah. Untuk mendapatkan gambaran pada kondisi pra siklus ini maka peneliti melakukan uji kompentesi pada siswa pada bidang studi Akuntansi Keuangan khususnya mengenai meteri pelajaran memposting buku besar. Hasil nilai uji kompetensi pada kondisi pra siklus adalah sebagai berikut:

Tabel 2. Nilai Uji Kompetensi Pra Siklus

\begin{tabular}{cllccccc}
\hline No & Kategori & Interval & $\mathbf{X}$ & $\mathbf{F}$ & $\mathbf{F}(\mathbf{X})$ & \% & Keterangan \\
\hline $\mathbf{1}$ & Amat Baik & $86-100$ & 93 & 4 & 372 & 18.84 & 68.10 \\
$\mathbf{2}$ & Baik & $70-85$ & 78 & 6 & 468 & 23.70 & \\
$\mathbf{3}$ & Cukup & $60-69$ & 65 & 9 & 585 & 29.62 & \\
$\mathbf{4}$ & Kurang & $\leq 59$ & 55 & 10 & 550 & 27.85 & \\
& Jumlah & & & 29 & 1975 & 100,00 & CUKUP \\
\hline
\end{tabular}

Dari hasil uji kompetensi diatas dapat diketahui bahwa nilai rata-rata siswa sebesar 68,10 , dimana nilai tersebut masih dibawah standar sehingga perlu ditingkatkan. Peneliti berupaya untuk mengatasi permasalahan tersebut dengan menerapkan metode baru dalam pelaksanaan pembelajaran Akuntansi Keuangan, yaitu dengan menerapkan metode resitasi bahan ajar untuk memposting transaksi pembelian dan penjualan ke dalam buku besar. Melalui penerapan metode baru tersebut diharapkan terjadi peningkatan dalam pembelajaran Akuntansi Keuangan, sehingga nilai akademis siswa dapat meningkat pula. 


\subsection{Hasil Pelaksanaan Tindakan}

\subsubsection{Siklus 1}

Pada awal tindakan peneliti yang juga berperan sebagai guru pengampu pelajaran meberikan penjelasan pada siswa mengenai penerapan metode pembelajaran yang baru. Diamana siswa akan diajarkan untuk resitasi bahan ajar memposting transaksi kedalam buku besar. Sehingga tidak ada perbedaan persepsi salama pelaksanaan pembelajaran.

1. Tindakan Perencanaan

a. Setelah melakukan sosialisasi dan penjelasan mengenai metode baru yang akan diterapkan, maka selanjutnya peneliti mempersiapkan materi yang akan di ajarkan kepada siswa yaitu tentang kegiatan memposting ke buku besar.

b. Kemudian peneliti menetapkan rancangan langkah-langkah kegiatan yang akan dilakukan ketika melakukan proses belajar mengajar.

\section{Observasi dan Penilaian}

\section{a. Hasil Aktivitas Belajar Siswa}

Berdasarkan hasil observasi keaktifan pada pertemuan pertama, terdapat 17 siswa aktif atau 50,0\% dari 34 siswa yang hadir. Berdasarkan data tersebut, dapat ditafsirkan bahwa target penelitian belum dapat tercapai. Observasi aktivitas setiap siswa dicatat dalam lembar observasi aktivitas yang dilakukan oleh satu orang observer dan diamati selama proses pembelajaran berlangsung. Pelaksanaan observasi meliputi 7 jenis aktivitas siswa yaitu memperhatikan penjelasan guru, bertanya kepada guru, mencatat/menyalin/menulis hasil, mengerjakan LKS, menjawab/menanggapi pertanyaan, membuat kesimpulan, mengerjakan soal latihan.

b. Hasil Belajar Kelompok

Dari data hasil belajar kelompok/diskusi pada siklus 1 diperoleh hasil Keaktivan siswa menjelaskan materi katagori baik sebesar 35,4\%, cukup 32,3\% dan kurang sebesar 32,3\%. Mendengarkan penjelasan teman katagori baik sebesar 35,4\%, cukup $38,2 \%$ dan kurang sebesar $26,4 \%$. Siswa yang menjawab pertanyaan kelompok lain katagori baik sebesar 26,5\%, cukup $47 \%$ dan kurang sebesar $26,5 \%$. Sedangkan siswa yang menghargai pendapat teman katagori baik sebesar 35,4\%, cukup 35,4\% dan kurang sebesar $29,2 \%$.

c. Hasil Belajar Individu

Dari data hasil belajar siswa pada siklus Iyang diperoleh dari tugas siklus I. menunjukkan siswa yang memperoleh nilai $\geq 60$ sebanyak 25 siswa dari 34 siswa atau $73,52 \%$. Hal ini berarti masih 9 siswa atau $26,47 \%$ siswa yang hasil belajarnya kurang dari 60 , artinya masih terdapat 9 siswa yang masih mengalami kesulitan belajar. Hal ini menjadi acuan untuk ditingkatkan kembali pada pertemuan berikutnya agar siswa yang mengalami kesulitan dapat teratasi. Pada umumnya siswa yang memperoleh nilai rendah adalah siswa yang aktifitasnya rendah. Hasil siklus I belum memenuhi indicator keberhasilan yang diharapkan yaitu $75 \%$ siswa yang memperoleh nilai lebih atau sama dengan 60.

3. Refleksi

Pada akhir siklus 1, terdapat beberapa faktor yang menyebabkan pembelajaran tipe kooperatif Metode Resitasi Melalui Bahan Ajar LKS (Student Work Sheet) belum memenuhi kondisi yang diharapkan, yaitu:

a. Guru belum dapat mengatur waktu dengan baik, karena meskipun siswa sudah berperan aktif dalam kegiatan diskusi dan presentasi namun waktu guru untuk membahas dan memberi kesimpulan terkadang masih kurang. 
b. Pada proses pembelajaran siswa masih banyak yang bingung, ini terjadi karena mereka belum terbiasa dengan Metode Resitasi Melalui Bahan Ajar LKS (Student Work Sheet).

Oleh karena itu, perlu adanya perbaikan yang akan diterapkan pada pertemuan kedua.

\subsubsection{Siklus 2}

1. Tindakan Perencanaan

Pada siklus II peneliti kembali melakukan peningkatan dalam pembelajaran Akuntansi Keuangan. Siklus II diawali dengan menyusun rencana perbaikan yang nantinya akan diimplementasikan dalam pelaksanaan. Dengan memadukan hasil refleksi daur I dan rencana daur II, diharapkan terjadi peningkatan kemampuan siswa dalam memposting. Maka peneliti kembali menyusun rencana perbaikan pembelajaran.

a. Peneliti mengelolaan waktu pembelajaran dengan optimal.

b. Mengarahkan siswa agar mereka terbiasa dengan pembelajaran dengan Metode Resitasi Melalui Bahan Ajar LKS (Student Work Sheet).

c. Mengarahkan siswa untuk berdiskusi dengan kelompoknya masing-masing, dan menegur siswa yang pasif saat diskusi.

2. Observasi dan Penilaian

\section{a. Hasil Belajar Kelompok}

Dari data hasil belajar kelompok/diskusi pada siklus 2 diperoleh hasil keaktifan siswa menjelaskan materi terletak pada katagori baik sebesar 38,2\%, cukup 35,3\% dan kurang sebesar 26,5\%. Mendengarkan penjelasan teman katagori baik sebesar 38,2\%, cukup $32,3 \%$ dan kurang sebesar $29,5 \%$. Siswa yang menjawab pertanyaan kelompok lain katagori baik sebesar 38,2\%, cukup 32,3\% dan kurang sebesar 29,5\%. Sedangkan siswa yang menghargai pendapat teman katagori baik sebesar $41 \%$, cukup $26,5 \%$ dan kurang sebesar $29,5 \%$.

b. Hasil Belajar Individu

Data hasil belajar siswa pada siklus II menunjukkan siswa yang memperoleh nilai $\geq 60$ sebanyak 28 siswa dari 34 siswa atau $82,35 \%$. Hal ini berarti masih 6 siswa atau $17,65 \%$ siswa yang hasil belajarnya kurang dari 60 , artinya masih terdapat 9 siswa yang masih mengalami kesulitan belajar.

\section{Refleksi}

Meskipun telah terjadi peningkatan aktivitas dan hasil belajar siswa pada siklus 2, namun masih ada beberapa permasalahan yaitu :

a. Masih ada beberapa siswa yang tidak berdiskusi dengan kelompoknya saat diskusi kelompok berlangsung

b. Ada beberapa siswa yang tidak memperhatikan guru saat guru menjelaskan materi

c. Terdapat beberapa siswa yang tidak mengerjakan soal - soal latihan

Oleh karena itu, perlu adanya perbaikan yang akan diterapkan pada siklus 3 .

\subsubsection{Siklus III}

1. Tindakan Perencanaan

Pada siklus III peneliti kembali melakukan peningkatan dalam pembelajaran Akuntansi Keuangan. Siklus III diawali dengan menyusun rencana perbaikan yang 
nantinya akan diimplementasikan dalam pelaksanaan. Dengan memadukan hasil refleksi I dan II, diharapkan terjadi peningkatan kemampuan siswa dalam memposting. Maka peneliti kembali menyusun rencana perbaikan pembelajaran.

a. Peneliti mengarahkan siswa agar mereka terbiasa dengan pembelajaran dengan Metode Resitasi Melalui Bahan Ajar LKS (Student Work Sheet).

b. Mengarahkan siswa untuk berdiskusi dengan kelompoknya masing-masing, dan menegur siswa yang pasif saat diskusi

2. Observasi dan Penilaian

a. Hasil Belajar Kelompok

Data hasil belajar kelompok/diskusi pada siklus 3 diperoleh hasil Keaktivan siswa menjelaskan materi katagori baik sebesar 50,0\%, cukup26,47\% dan kurang sebesar 23,53\%. Mendengarkan penjelasan teman katagori baik sebesar 52,94\%, cukup26,47\% dan kurang sebesar $20,58 \%$. Siswa yang menjawab pertanyaan kelompok lain katagori baik sebesar 52,94\%, cukup26,47\% dan kurang sebesar $20,58 \%$. Sedangkansiswa yang menghargai pendapat teman katagori baik sebesar $50,0 \%$, cukup $29,41 \%$ dan kurang sebesar 20,59\%.

\section{b. Hasil Belajar Individu}

Data hasil belajar siswa pada siklus 3 menunjukkan siswa yang memperoleh nilai $\geq 60$ sebanyak 30 siswa dari 34 siswa atau $88,20 \%$. Hal ini berarti masih 4 siswa atau $11,8 \%$ siswa yang hasil belajarnya kurang dari 60 , artinya masih terdapat 4 siswa yang masih mengalami kesulitan belajar.

3. Refleksi

Meskipun telah terjadi peningkatan aktivitas dan hasil belajar siswa pada siklus 3, namun masih ada beberapa permasalahan yaitu :

a. Masih ada beberapa siswa yang tidak berdiskusi dengan kelompoknya saat diskusi kelompok berlangsung

b. Ada beberapa siswa yang tidak memperhatikan guru saat guru menjelaskan materi

c. Terdapat beberapa siswa yang tidak mengerjakan soal-soal latihan

\subsection{Pembahasan}

Pada bagian ini akan membandingkan hasil yang diperoleh pada setiap siklus. Pada kondisi pra siklus pelaksanaan pembelajaran Akuntansi Keuangan masih menggunakan metode pembelajaran yang tradisional sehingga belum diterapkan metode resitasi bahan ajar untuk memposting tarnsaksi pembelian dan penjualan ke dalam buku besar. Metode ini dinilai kurang efektif sehingga siswa tidak dapat menyerap ilmu pelajaran yang disampaikan dan tidak memahami tentang teknik memposting yang tepat. Kemampuan pada siswa yang kurang menyebabkan perolehan nilai pada uji kompetensi menjadi minim yaitu sebesar 68,10. Berdasarkan nilai interval yang dibuat peneliti maka nilai tersebut tergolong cukup. Siswa yang memperoleh nilai antara 86-100 belum ada.

Untuk mengatasi kendala tersebut maka peneliti melakukan perubahan pada pelaksanaan pembelajaran dengan menerapkan metode resitasi bahan ajar memposting pada buku besar. Pada siklus I siswa diberikan buku materi pelajaran Akuntansi Keuangan, peneliti memberikan penjelasan mengenai materi pelajaran kemudian memberikan tugas pada siswa. Hasil uji kompetensi pada siklus I mengalami peningkatan menjadi 71,62, dimana siswa yang memperoleh nilai 86-100 sebanyak enam orang dan tergolong dalam kategori baik. Peneliti kembali magadakan perubahan pada siklus II dengan memberikan contoh-contoh soal mengenai teknik memposting pada siswa. Sehingga siswa lebih memahami cara memposting ke buku 
besar. Hal ini di tunjukkan pada perolehan hasil uji kompetensi pada siklus II menjadi 74,31. Siswa yang memperoleh nilai 86-100 sebanyak sembilan orang.

Peningkatan hasil yang maksimal diperoleh pada siklus III yaitu sebesar 80,38, dimana siswa yang memperoleh nilai 86-100 sebanyak dua belas orang dari 29 siswa. Peningkatan ini diperoleh setelah peneliti menggunakan OHP sebagai sarana pengajaran dan memberikan tugas rumah pada siswa.

Tabel 3. Peningkatan Nilai Setiap Siklus

\begin{tabular}{lcccc}
\hline Keterangan & Pra Siklus & Siklus I & Siklus 2 & Siklus 3 \\
\hline Nilai Ujian Kompetensi & 68,10 & 71,62 & 74,31 & 80,38 \\
\hline
\end{tabular}

\section{Kesimpulan}

Berdasarkan hasil penelitian dapat disimpulkan bahwa Pembelajaran dengan menggunakan Metode Resitasi Bahan Ajar Lembar Kerja Siswa dapat meningkatkan prestasi belajar Akuntansi siswa Kelas XI AKUNTANSI 2 SMK Negeri 1 Rengat tahun 2017. Pada kondisi pra siklus pelaksanaan pembelajaran menggunakan metode pembelajaran tradisional masih kurang efektif sehingga siswa tidak dapat menyerap ilmu yang disampaikan dan tidak memahami tentang teknik memposting yang tepat dengan nilai uji kompetensi 68,10 yang tergolong cukup serta belum ada siswa memperoleh nilai 86-100. Peningkatan maksimal diperoleh pada siklus III dengan nilai hasil uji kompetensi menjadi 80,38 dan jumlah siswa yang memperoleh nilai 86-100 meningkat menjadi 12 (dua belas) orang. Peningkatan ini diperoleh setelah peneliti menggunakan OHP sebagai sarana pengajaran dan memberikan tugas rumah pada siswa.

\section{Daftar Pustaka}

[1] Bloom, Benyamin, S. 1974. Taxonomy of Educational Objectives. New York: David, Mc. Coy, Inc.

[2] Departemen Pendidikan dan Kebudayaan. 1993. Profil Kemampuan Guru Sekolah Lanjutan, Jakarta : Ditjen Dikti Depdikbud.

[3] Jurusan PPB-IKIP Bandung. 1986. Psikologi Pembelajaran dan Pengajaran. Bandung.

[4] Miles B. Matthew dan Huberman A. Michael. 1992. Analisis Data Kualitatif. Jakarta: UI Press

[5] Moleong, Lexy. 2006. Metodologi Penelitian Kualitatif. Bandung: Remaja Karya

[6] Natawidjaja, Rochman. 1996. Pokok-pokok Pikiran mengenai Penelitian Keias, Makalah. Jakarta: Ditjen Dikti Dikbud.

[7] Sardiman, A.M. 1996. Interaksi dan Motivasi Belajar Mengajar. Jakarta: Raja Grafindo Persada.

[8] Sudibyo dkk. 2002. Prinsip Prinsip Akuntansi Untuk SMU/ Sederajat. Bogor: Yudistira.

[9] Sudjana, Nana. 1995. Dasar-dasar Proses Belajar Mengajar, Bandung: Sinar Baru Algesindo.

[10] Sumantri, Hendi. 2000. Akuntansi Keuangan SMK. Bandung: Amriko.

[11] Sutopo, H.B. 2002. Metodologi Penelitian Kualitatif. UNS Press.

[12] Suyoto. 1996. Akuntansi Keuangan Untuk Sekolah Menengah Kejuruan Kelompok Bisnis dan Manajemen. Bandung: Titian Ilmu. 
[13] Wiriaatmadja, Rochiati. 2007. Metode Penelitian Tindakan Kelas. Bandung: Remaja Rosdakarya.

[14] Zainal, Aqib. 2006. Penelitian Tindakan Kelas. Bandung: Yrama Widya.

[15] Zaini, Hisyam. 2007. Strategi Pembelajaran Aktif. Yogyakarta: CTSD. 